\title{
Neurological Complication of Infective Endocarditis Mimicking Temporal Arteritis
}

\author{
Valeria Terruso ${ }^{\mathrm{b}}$ Ivan Bonanni ${ }^{\mathrm{a}}$ Lavinia Dinia $^{\mathrm{a}} \quad$ Cinzia Canepa $^{\mathrm{a}} \quad$ Carlo Gandolfo $^{\mathrm{a}}$ \\ Massimo Del Sette ${ }^{a}$ \\ ${ }^{a}$ Department of Neuroscience, Ophthalmology and Genetics, University of Genova, Genova, and ${ }^{b}$ Department of \\ Neurology, Ophthalmology, Otorhinolaryngology and Psychiatry, University of Palermo, Palermo, Italy
}

\begin{abstract}
Dear Sir,
Infective endocarditis (IE) can present with systemic embolizations [1], which most frequently involve the central nervous system [2]. Intracerebral or subarachnoid hemorrhage (SAH), due to the rupture of mycotic aneurysm or to the rupture of pyogenic arteritis, is a less frequent complication of IE [3]. A few cases of retinal arterial occlusion as a complication of infectious endocarditis have been described [4-6].

We report the case of an uncommon presentation of infectious endocarditis with concomitant ischemic and hemorrhagic manifestations in the central nervous system, with clinical aspects similar to temporal arteritis.
\end{abstract}

\section{Case Report}

An 80-year-old man was admitted to our Department for sudden onset of severe headache, delirium and visual impairment with 'dark shadows' in both eyes. Personal history revealed reported diffuse arthralgias, anemia, elevation of ESV and C-reactive protein, previously interpreted as polymyalgia rheumatica. He also had multiple parodontopathies. Neurological examination showed the presence of meningeal signs and confusional state. A cerebral CT scan showed a suprasellar SAH, extending toward pons and occipital lobes. General examination showed cardiac systolic apical murmur. Blood tests confirmed the presence of anemia (RBC 3,000,000 $\mathrm{mm}^{3}, \mathrm{Hb}$ $9 \mathrm{M})$, elevation of C-reactive protein (106 M) and fibrinogen $(816 \mathrm{M})$. Angio-CT of cerebral vessels did not show any aneurysm or vascular malformation. We decided to submit the patient to angio-CT, although CT is not the gold standard test to detect intracranial mycotic aneurysms, because of patients' age and general conditions. A retinal fluoroangiography documented an acute ischemic optic neuropathy with bilateral branches occlusion of retinal arteries. Blood cultures showed the presence of Streptococcus anginosus, and a transthoracic echocardiography showed endocardic strands in mitral and pulmonary valves with severe mitral regurgitation. Intravenous antibiotic therapy with gentamicin and ampicillin/sulbactam was started. A follow-up CT scan done after 1 week from admission, 2 days after antibiotic treatment was started, showed an asymptomatic small parenchymal left occipital hemorrhage. The patient was evaluated by cardiosurgeons, who suggested valve replacement, and he underwent surgical intervention a month after discharge from our ward. No neurological or cardiological complication followed cardiac surgery, and neurological examination 1 month after surgery showed only bilateral blurred vision, without focal neurological signs.

\section{Discussion}

We report the case of an 80-year-old man with a cryptogenic SAH concomitant to an embolic event in the retinal arterial tree and a subsequent asymptomatic small occipital hemorrhage. Differential diagnosis was relevant to therapeutic options. In fact, personal history of polymyalgia, presence of inflammatory markers and evidence of retinal ischemia at first suggested the diagnosis of temporal arteritis. This vasculitis may present with systemic signs such as anemia, fever, headache, stroke and polymyalgia [7]. Moreover, ocular symptoms (from ischemic optic neuropathy to retinal artery occlusion) are often present in temporal arteritis $[8,9]$. Cerebral hemorrhage is rarely associated with giant cell arteritis. Thal et al. [10] described the case of a young girl with giant cell arteritis associated with vertebral artery aneurysm and SAH. Muller et al. reported a patient with temporal arteritis who developed cerebral hemorrhage, pulmonary infiltrates and glomerulonephritis [11]. In

\section{KARGER}

Fax +41 613061234

E-Mail karger@karger.ch

www.karger.com (c) 2008 S. Karger AG, Basel

$0014-3022 / 08 / 0594-0198 \$ 24.50 / 0$

Accessible online at:

www.karger.com/ene
Massimo Del Sette

Department of Neuroscience, Ophthalmology and Genetics, University of Genova

Via De Toni 5

IT-16132 Genova (Italy)

Tel. +39010 353 7040, Fax +39010353 8625, E-Mail mdelsette@neurologia.unige.it 
our case, the presence of cardiac murmur, the positivity of blood culture and the evidence of valvular strands confirmed the diagnosis of IE.

Central nervous system complications occurring during IE are classified as cerebrovascular (TIA/stroke and/or hemorrhage), infectious (meningitis and abscess) and nonspecific (encephalopathy, seizures and headaches), with stroke being the most common complication [12]. Hart et al. [13], in a consecutive series of IE, found cerebrovascular events in $21 \%$ of cases $(17 \%$ ischemic stroke/TIA, $6 \%$ brain hemorrhage). Intracerebral or subarachnoid hemorrhages, usually due to rupture of mycotic aneurysms, are reported in 2.7$7 \%$ of patients with IE [14-16]. However, case reports of SAH as a presenting feature of IE are not frequent [12-16]. Chukwudelunzu et al. [17], in a series of 489 patients with IE, found SAH only in $1 \%$, and mycotic aneurysms were identified in only 2 out of 8 cases.

SAH and retinal embolism are common neurological sequelae of IE. The interesting feature of our case is that the concomitance of these two complications mimicked temporal arteritis that should be considered in the differential diagnosis.

\section{References}

1 Hermans PE: The clinical manifestations of infective endocarditis. Mayo Clin Proc 1982; 57:15-21.

2 Bayer AS, Bolger AF, Taubert KA, et al: Diagnosis and management of infective endocarditis and its complications. Circulation 1998;98:2936-2948.

3 Masuda J, Yutani C, Waki R, Ogata J, Kuriyama Y, Yamaguchi T: Histopathological analysis of the mechanisms of intracranial hemorrhage complicating infective endocarditis. Stroke 1992;23:843-850.

4 Schimdt D, Zehender M: Arterial occlusion of the eye in infectious endocarditis. Ophthalmologe 1999;96:264-266

5 Beatty S, Harrison RJ, Roche P: Bilateral macular holes resulting from septic embolization. Am J Ophthalmol 1997;13:557-559.

6 Kim JE, Han DP: Premacular hemorrhage as a sign of subacute bacterial endocarditis. Am J Ophthalmol 1995;120:250-251.

7 Eshaghian J: Controversies regarding giant cell (temporal, cranial) arteritis. Doc Ophthalmol 1979;47:43-67.

8 Cohen DN, Damaske MM: Temporal arteritis: a spectrum of ophthalmic complications. Ann Ophthalmol 1975;7:1045-1054.

9 Slavin ML, Barondes MJ: Visual loss caused by choroidal ischemia preceding anterior ischemic optic neuropathy in giant cell arteritis. Am J Ophthalmol 1994;117:81-86.
10 Thal DR, Barduzal S, Franz K, Herrmann G, Bode F, Lambrecht E, Schlote W: Giant cell arteritis in a 19-year-old woman associated with vertebral artery aneurysm and subarachnoid hemorrhage. Clin Neuropathol 2001;20:80-86

11 Muller E, Schneider W, Kettritz U, Schmidt WA, Luft FC, Gobel U: Temporal arteritis with pauci-immune glomerulonephritis: a systemic disease. Clin Nephrol 2004;62:384386.

12 Salgado AV: Central nervous system complications of infective endocarditis. Stroke 1991;26:19-22.

13 Hart RG, Foster JW, Luther MF, Kanter MC: Stroke in infective endocarditis. Stroke 1990; 21:695-700.

14 Jones HR, Siekert RG, Geraci JE: Neurological manifestations of bacterial endocarditis. Ann Intern Med 1969;71:21-28.

15 Salgado AV, Furlan AJ, Keyes TF: Mycotic aneurysms, subarachnoid hemorrhage, and indications for cerebral angiography in infective endocarditis. Stroke 1987;18:10571060.

16 Pruitt AA, Rubin RH, Karchmer AW, Duncan GW: Neurologic complications of bacterial endocarditis. Medicine 1978;57:329343.

17 Chukwudelunzu FE, Brown RD, Wijdicks EFM, Steckelberg JM: Subarachnoid haemorrhage associated with infectious endocarditis: case report and literature review. Eur J Neurol 2002;9:423-427. 